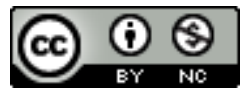

Jurnal Pendidikan Matematika Indonesia is licensed under A Creative Commons Attribution-Non Commercial 4.0 International License.

\title{
Profil Kemampuan Guru dalam Merancang Soal/Permasalahan MATEMATIKA DITINJAU DARI TAKSONOMI BLOOM
}

\author{
Baiq Rika Ayu Febrilia \\ IKIP Mataram, Mataram, Indonesia \\ E-mail: rika.febrilia@gmail.com
}

\begin{abstract}
Abstrak. Kemampuan guru dalam mendesain soal/permasalahan matematika mempengaruhi kualitas pembelajaran matematika di kelas. Besarnya frekuensi guru dalam memberikan soal tertutup membuat penalaran dan kreatifitas siswa kurang berkembang dengan baik. Akibatnya, jika siswa dihadapkan dengan permasalahan berbeda dari yang mereka sering dapatkan, siswa cenderung menunjukkan sikap bingung dan merasa kesulitan dalam mencari solusi dari permasalahan tersebut. Penelitian ini bertujuan untuk mendeskripsikan kemampuan guru dalam merancang soal matematika ditinjau dari level kemampuan berpikir Taksonomi Bloom yang direvisi oleh Krathwohl. Penelitian dengan jenis kualitatif deskriptif ini melibatkan tujuh orang guru matematika SMP/MTs di Kota Mataram. Hasil penelitian ini menunjukkan bahwa dari 14 permasalahan yang dirancang oleh 7 orang guru, 9 diantaranya berada pada level aplikasi, 1 permasalahan pada level pemahaman, 1 permasalahan pada level analisis dan 3 permasalahan pada level evaluasi.
\end{abstract}

Keywords: rancangan permasalahan matematika, taksonomi Bloom

\section{Pendahuluan}

Guru matematika haruslah memiliki kemampuan dalam mempersiapkan bahan dan alat yang akan diajarkan serta desain strategi pembelajaran matematika (Siregar, 2015), termasuk kemampuan dalam merancang soal/permasalahan matematika (Fatimah dan Amam, 2018). Guru merancang suatu permasalahan dapat bertujuan untuk mengukur bagaimana kemampuan siswa dalam memahami, mencermati dan mengingat materi yang telah diperoleh atau mengukur kemampuan siswa dalam memanfaatkan dan mengaplikasikan materi yang telah diperoleh pada ha yang baru (Mayer, 2009). Oleh karena itu, guru perlu memiliki kemampuan dalam merancang soal/permasalahan yang pantas untuk memperoleh tujuan yang diinginkan.

Soal/permasalahan yang dirancang oleh guru mempengaruhi cara pandang, komunikasi matematis, metode berpikir, sikap, kemampuan pemecahan masalah dan penalaran siswa (Anisah dkk, 2011; Mardhiyanti dkk, 2011; Silva dkk, 2011), kemampuan dalam menganalisis berbagai macam ide, mensintesis hasil, mencari persamaan dan perbedaan dan melakukan evaluasi terhadap hasil temuan (Febrilia \& Juliangkary, 2018). Posisi Indonesia yang berada pada peringkat 5 terendah di bidang matematika berdasarkan hasil survei PISA tahun 2009 menunjukkan bahwa kemampuan siswa dalam berkomunikasi matematis, berpikir dan bernalar tergolong rendah. Oleh karena itu, kemampuan guru dalam merancang soal/permasalahan sangat diperlukan untuk mendorong siswa agar dapat memaknai suatu konsep atau konten matematika secara lebih mendalam dan pada akhirnya siswa akan menjadi terlibat aktif selama mengikuti pembelajaran matematika (Juliangkary \& Febrilia, 2018).

Siswono (2007) menyebutkan bahwa ketika seorang guru merancang soal/permasalahan matematika, guru harus memperhatikan aspek isi materi, konteks dan konstruksi permasalahan serta pemilihan kata dan kalimat yang digunakan. Siswono juga menjelaskan bahwa materi yang ada pada rancangan tugas haruslah materi yang sudah dipelajari siswa, terdapat keterkaitan antar konsep dalam matematika serta merupakan permasalahan yang sesuai dengan level kognitif siswa. Permasalahan dapat berupa kegiatan pemecahan masalah atau kegiatan lainnya yang tersusun atas beberapa butir-butir pertanyaan. Butir pertanyaan ini akan menuntun siswa pada cara penyelesaian dari masalah yang diajukan. Guru juga perlu memperhatikan pemilihan kata dan susunan kalimat yang digunakan. Bahasa haruslah sesuai dengan aturan Ejaan yang Disempurnakan (EYD), komunikatif dan sesuai dengan kemampuan bahasa siswa.

Kemampuan guru dalam merancang soal/permasalahan sangat menarik dan penting untuk dibahas karena pengaruh 


\section{- - - Jurnal Pendidikan Matematika Indonesia \\ Volum 4 Nomor 2 bulan September 2019 Page 73 - 78 \\ p-ISSN: 2477-5967 e-ISSN: 2477-8443}

penerapannya yang cukup besar dalam membentuk karakteristik siswa dan kualitas dari pembelajaran yang guru terapkan (Lewy dkk, 2009). Pembelajaran matematika yang sarat akan rumus dan langkah-langkah dengan prosedur tertentu membuat guru cenderung memperbanyak frekuensi pemberian soal yang bersifat prosedural dan melatih ingatan siswa terhadap rumus dan prosedur tersebut. Akibatnya, siswa tidak terbiasa dengan bentuk-bentuk permsalahan yang lebih aplikatif dan berhubungan dengan kehidupan seharihari. Hal ini juga didukung oleh hasil analisis video TIMSS (2010) yang menunjukkan bahwa siswa terbiasa mengerjakan soal tertutup yang cara penyelesaiannya hanya menggunakan satu metode dan tidak mendukung adanya variasi jawaban. Dampak dari hal ini adalah tidak berkembangnya penalaran dan pemahaman siswa. Padahal, siswa sebaiknya diberikan kesempatan untuk dihadapkan pada masalah kontekstual yang mengkoneksikan berbagai macam konsep yang telah siswa pelajari (Fitriati \& Novita, 2015).

Kemampuan guru dalam merancang suatu soal atau permasalahan dapat ditinjau dari level berpikir apa yang mampu permasalahan tersebut munculkan dari dalam diri siswa. Salah satu level berpikir yang dapat dijadikan acuan adalah level berpikir yang diperkenalkan oleh Bloom (1956) atau biasa dikenal dengan istilah Taksonomi Bloom. Kemampuan berpikir dalam Taksonomi Bloom terdiri atas kemampuan berpikir tingkat rendah termasuk pengetahuan dan pemahaman dan berpikir tingkat tinggi termasuk aplikasi, analisis, sintesis dan evaluasi (Thompson, 2008). Dalam hal ini, pemahaman memiliki karakter sebagai pengunaan prosedur atau langkah-langkah yang telah diketahui, sedangkan aplikasi adalah penggunaan pemahaman pada situasi baru,serta pemecahan masalah dengan menggunakan langkah-langkah atau metode yang belum dipelajari. Krathwohl (2002) melakukan revisi terhadap bentuk awal Taksonomi Bloom dengan memperhatikan struktur dari proses kognitif. Perubahan ini menghasilkan 6 level kemampuan berpikir siswa, yaitu mengingat, memahami, mengaplikasikan, menganalisis, mengevaluasi dan mencipta (lihat Tabel 1). Hasil revisi ini dipercaya memberikan dapat memberikan gambaran yang lebih baik dan lebih spesifik mengenai bagaimana proses kognitif siswa.

Hasil studi penelitian terdahulu menunjukkan bahwa beberapa peneliti terfokus dalam melihat bagaimana tingkat kognitif dari soal-soal yang ada pada buku matematika siswa di sekolah (Giani dkk, 2015; Rufiani, 2015). Belum banyak penelitian yang menyoroti mengenai bagaimana sisi kognitif dari soal/permasalahan yang selama ini guru rancang dan berikan kepada siswa di kelas.

Berdasarkan uraian di atas, maka dipandang penting untuk mengetahui profil kemampuan guru dalam merancang soal/permasalahan matematika untuk memperoleh gambaran mengenai jenis-jenis soal/permasalahan dan level kemampuan berpikir yang dapat didorong melalui jenis soal tersebut. Harapannya, hasil ini dapat menjadi bahan refleksi untuk memperbaiki dan meningkatkan kemampuan guru dalam merancang soal/permasalahan matematika. Hasil ini juga dapat dijadikan sebagai acuan untuk mempersiapkan literasi dan pedoman dalam merancang soal/permasalahan yang mampu mendorong kemampuan berpikir siswa pada level yang lebih tinggi.

\section{Metode Penelitian}

Metode penelitian yang digunakan pada penelitian ini adalah penelitian kualitatif deskriptif yang menghasilkan gambaran secara lebih rinci mengenai kemampuan guru dalam merancang soal/permasalahan matematika. Subjek yang terlibat adalah tujuh orang guru matematika SMP/MTs yang mengajar di Kota Mataram. Guru ini terdiri atas dua orang laki-laki dan lima orang perempuan.

Kemampuan guru dalam merancang soal/permasalahan matematika ditinjau dari level Taksonomi Bloom yang muncul pada rancangan tersebut. Proses pengumpulan data menggunakan lembar kerja guru di mana guru diminta untuk membuat soal/permasalahan pada dua topik matematika SMP.

Analisis fokus kepada kemampuan guru dalam merancang soal ditinjau dari level kemampuan berpikir siswa pada Taksonomi Bloom hasil revisi oleh Krathwohl (2002). Level kemampuan berpikir yang dimaksud diringkas pada Tabel 1. Soal/permasalahan rancangan guru dapat mendorong munculnya level kemampuan berpikir tingkat tinggi siswa jika soal/permasalahan tersebut berada pada level analisis, evaluasi dan mencipta (Krathwohl, 2002).

TABEL 1

LEVEL KeMAMPUAN BERPIKIR MENURUT KRATHWOHL (2002)

\begin{tabular}{|c|c|}
\hline $\begin{array}{c}\text { Level Kemampuan } \\
\text { Berpikir }\end{array}$ & Deskripsi \\
\hline 1. Mengingat (IG) & $\begin{array}{l}\text { Memunculkan pengetahuan } \\
\text { dari memori jangka panjang } \\
\text { siswa. } \\
\text { Contoh: menyatakan dan } \\
\text { mengingat kembali }\end{array}$ \\
\hline Memahami (PH) & $\begin{array}{l}\text { Menjelaskan makna dari } \\
\text { suatu hal. } \\
\text { Contoh: memberi contoh, } \\
\text { menjelaskan }\end{array}$ \\
\hline $\begin{array}{l}\text { 3. Mengaplikasikan } \\
(\mathrm{PL})\end{array}$ & $\begin{array}{l}\text { Menggunakan langkah- } \\
\text { langkah pada keadaan } \\
\text { tertentu. } \\
\text { Contoh: menerapkan }\end{array}$ \\
\hline $\begin{array}{l}\text { 4. Menganalisis } \\
\text { (NL) }\end{array}$ & $\begin{array}{l}\text { Mengamati hubungan antara } \\
\text { satu hal dengan yang lain. } \\
\text { Contoh: menghubungkan }\end{array}$ \\
\hline $\begin{array}{l}\text { 5. Mengevaluasi } \\
\text { (VL) }\end{array}$ & $\begin{array}{l}\text { Memberikan penilaian atau } \\
\text { justifikasi terhadap suatu hal } \\
\text { berdasarkan alasan tertentu. } \\
\text { Contoh: memeriksa }\end{array}$ \\
\hline
\end{tabular}




\begin{tabular}{|c|c|}
\hline 6. Mencipta (CP) & $\begin{array}{l}\text { Membentuk suatu hal yang } \\
\text { baru dengan memadu } \\
\text { padankan beberapa } \\
\text { komponen. } \\
\text { Contoh: memproduksi }\end{array}$ \\
\hline
\end{tabular}

\section{HASIL DAN PEMBAHASAN}

Untuk meninjau kemampuan guru dalam merancang soal/permasalahan, ketujuh guru diminta untuk merancang dua soal/permasalahan dalam topik matematika yang berbeda. Hasil soal/permasalahan rancangan guru ini dianalisis menggunakan Taksonomi Bloom. Hasil penelitian menunjukkan bahwa masih banyak yang berbentuk soal tertutup, mengkehendaki satu jawaban benar dengan metode yang telah umum digunakan seperti pada Gambar 1 di bawah ini.

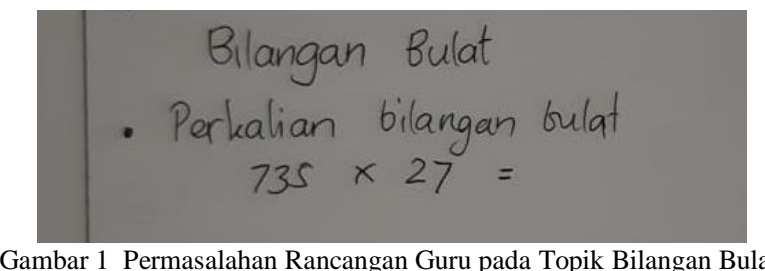

Berdasarkan gambar di atas, guru meminta siswa untuk menghitung atau menentukan hasil perkalian dari dua bilangan ratusan dan puluhan. Meskipun untuk beberapa siswa permasalahan ini mungkin dirasa sulit, tetapi soal/permasalahan semacam ini sudah lumrah diberikan oleh guru kepada siswa. Permasalahan ini menggiring siswa untuk memperoleh sebuah jawaban yang benar dengan langkah atau prosedur yang biasanya sudah diberikan oleh guru. Siswa hanya diminta untuk mengulang kembali langkah yang guru telah diberikan atau menerapkan pemahaman yang sebelumnya guru telah berikan dengan langkah-langkah yang telah ditentukan sebelumnya. Pada soal ini, siswa diminta untuk menerapkan prosedur pada soal yang sudah biasa dikerjakan dan termasuk bagian dari kegiatan mengeksekusi atau mengaplikasikan (Giani dkk, 2015). Oleh karenanya, berdasarkan Krathwohl (2002), level kemampuan berpikir tertinggi yang mungkin muncul melalui pengerjaan soal/permasalahan ini adalah level mengaplikasikan. Soal/permasalahan lainnya yang mampu memunculkan level berpikir mengaplikasikan adalah permasalahan hasil rancangan guru yang terdapat pada Gambar 2.

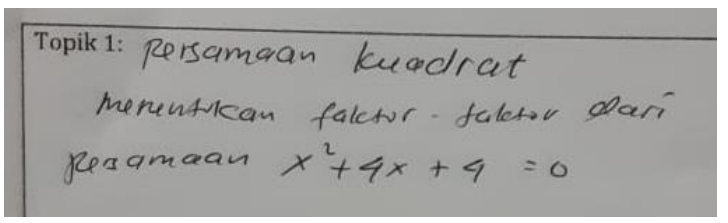

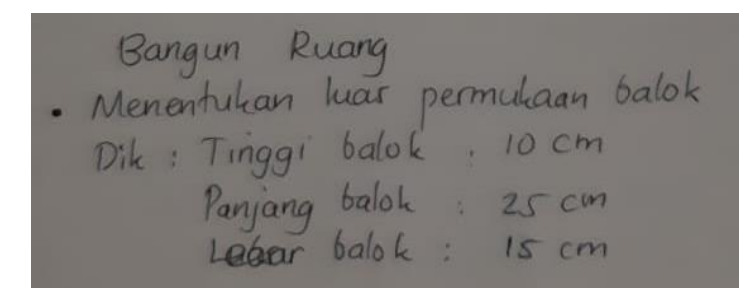

Gambar 2. Permasalahan Rancangan Guru pada Topik Persamaan Kuadrat dan Luas Permukaan Balok

Serupa dengan soal/permasalahan pada Gambar 1, soal/permasalahan pada Gambar 2 juga merupakan permasalahan yang sudah lumrah diberikan guru. Permasalahan pertama dalam gambar ini menuntut siswa untuk mencari faktor-faktor dari suatu persamaan kuadrat. Persamaan kuadrat yang diberikan dalam soal hanya memiliki 1 pasangan faktor yang mungkin dalam membentuknya. Untuk memperoleh pasangan faktor tersebut, biasanya siswa mengikuti langkah yang telah diberikan guru. Langkah yang lazim diberikan adalah menguraikan suku $4 x$ menjadi penjumlahan dua suku yang lain di mana dua koefisien dari dua suku pengurai suku $4 x$ apabila dikalikan akan menghasilkan suku 4. Dengan memperhatikan analisis ini, level tertinggi pemikiran siswa yang dapat didorong untuk muncul adalah level mengaplikasikan. Permasalahan kedua dalam gambar ini meminta siswa untuk menentukan luas permukaan balok dari beberapa unsur yang sudah diketahui. Dalam menentukan luas permukaan balok, siswa cenderung menggunakan rumus yang sudah ada dan sudah diberikan oleh guru. Permasalahan ini hanya memiliki satu jawaban yang benar. Bentuk permasalahan ini juga merupakan bentuk yang biasa guru berikan di kelas untuk melatih pemahaman siswa terhadap rumus atau prosedur yang telah siswa pelajari (Giani dkk, 2015).

Berbeda dengan soal/permasalahan pada Gambar 1 dan 2, soal/permasalahan yang ditunjukkan pada Gambar 3 hanya mampu memberikan kemampuan berpikir siswa pada level mengingat. Hal ini karena, soal yang dirancang guru tidak memerlukan keahlian khusus dalam mengoperasikan bilangan, membuat trik tertentu untuk memperoleh suatu jawaban atau melakukan analisis terhadap suatu keadaan. Pada soal ini, siswa hanya diminta untuk menentukan letak suatu titik dalam koordinat kartesius.

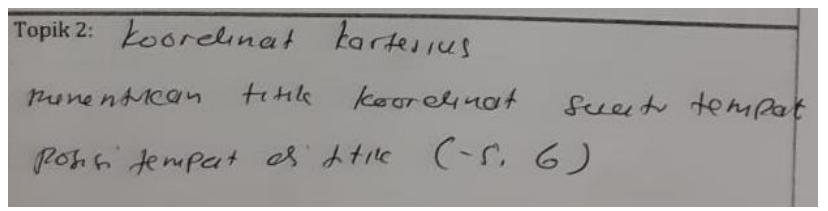

Gambar 3. Permasalahan Rancangan Guru pada Topik Koordinat Cartesius

Permasalahan pada Gambar 4 memiliki redaksional yang berbeda dengan permasalahan yang telah disebutkan sebelumnya. Pada permasalahan ini, siswa didorong untuk mengevaluasi, melakukan pengecekan kembali dan membuat justifikasi atas pernyataan yang diberikan dalam soal. Kegiatan mengevaluasi, memeriksa kembali dan menjustifikasi akan memberikan siswa kesempatan dalam 


\section{- - - Jurnal Pendidikan Matematika Indonesia \\ Volum 4 Nomor 2 bulan September 2019 Page 73 - 78 \\ p-ISSN: 2477-5967 e-ISSN: 2477-8443}

menunjukkan dan melatih keterampilan, kreativitas dan pemahaman konsep yang dimilikinya. Dalam melakukan evaluasi, pemeriksaan dan membuat justifikasi, siswa diberikan kesempatan untuk menggunakan langkah-langkah atau konsep yang telah mereka pelajari, melakukan pengamatan terhadap pola yang mungkin terbentuk atau bahkan sekedar mencoba-coba, sehingga kemampuan berpikir yang dapat diberikan melalui permasalahan ini adalah kemampuan mengevaluasi. Level mengevaluasi merupakan salah satu level yang dapat dikategorikan sebagai level berpikir tingkat tinggi

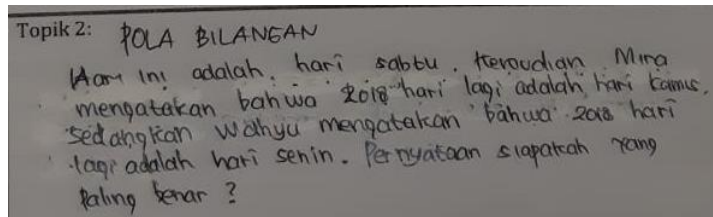

Gambar 4 Permasalahan Rancangan Guru pada Topik Pola Bilangan

Soal pada Gambar 5 merupakan soal yang memiliki tipe serupa dengan soal pada Gambar 4. Kalau diamati, soal ini seperti bentuk soal yang biasa ditemui, tetapi rancangan kalimat dalam soal membuat soal ini memiliki pandangan lain. Dengan mengerjakan soal ini, siswa diminta untuk menganalisis kembali atau melakukan pemeriksaan kembali terhadap pernyataan dua orang siswa lainnya. Kemudian siswa tersebut diminta untuk memberikan justifikasi pernyataan mana yang benar berdasarkan data yang dikumpulkan dan hasil analisis yang telah mereka lakukan. Kegiatan memeriksa kembali dan mengkritik suatu argumen merupakan bagian dari kegiatan mengevaluasi (Giani dkk, 2015), sehingga berdasarkan penjelasan dan hasil pengamatan ini, diduga soal/permasalahan semacam ini dapat membawa siswa kepada level pemikiran yang lebih tinggi, yaitu level mengevaluasi.

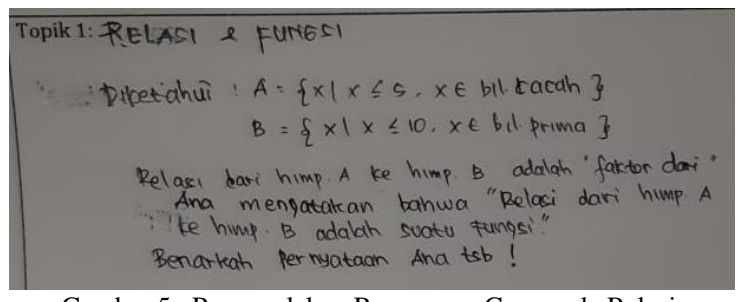

Gambar 5. Permasalahan Rancangan Guru pada Relasi

Guru juga merancang soal yang berkaitan dengan topik perbandingan senilai dan tak senilai seperti yang ditunjukkan pada Gambar 6. Berdasarkan pengamatan terhadap redaksional soal, permasalahan semacam ini juga belum keluar dari kebiasaan soal yang guru berikan ketika membelajarkan siswa pada topik perbandingan. Oleh karena itu, level pemikiran tertinggi yang mungkin didorong untuk muncul adalah level aplikasi.

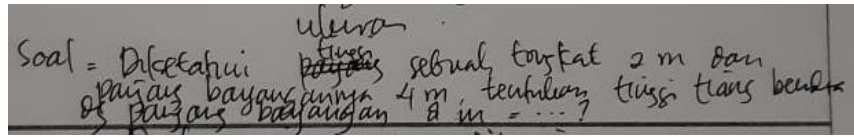

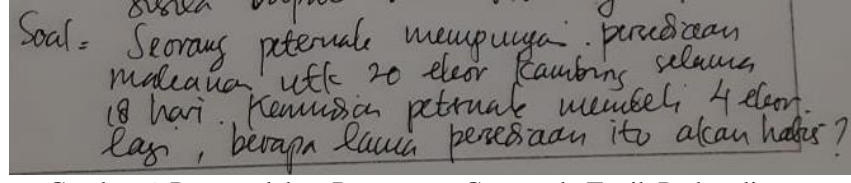

Gambar 6. Permasalahan Rancangan Guru pada Topik Perbandingan

Permasalahan berikutnya yang akan dibahas adalah permasalahan dalam bentuk akar (lihat Gambar 7). Kalau biasanya guru memberikan soal yang cenderung meminta siswa untuk melakukan proses perhitungan soal dan memberikan jawaban atau hasil atas proses yang telah dilakukan, permasalahan yang diberikan pada Gambar 7 meminta siswa untuk menjelaskan langkah yang digunakan pada untuk mendapatkan bentuk akar dari suatu bentuk yang diberikan. Penekanan yang diberikan pada permasalahan ini adalah bagaimana siswa menjelaskan suatu langkah atau cara untuk mrndapatkan hasilnya. Redaksional soal semacam ini hanya mampu mendorong siswa berpikir sampai pada level pemahaman. Siswa dituntut untuk menjelaskan kembali cara yang mereka akan lakukan dalam merasionalkan bentuk akar sesuai dengan apa yang mereka pahami berdasarkan atas informasi yang telah diberikan guru.

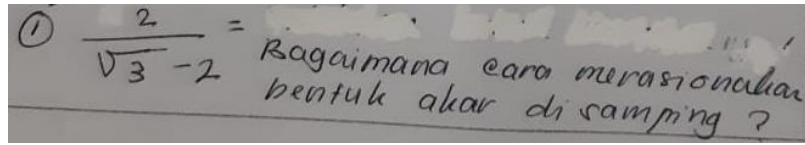

Gambar 7. Permasalahan Rancangan Guru pada Topik Bentuk Akar

Bentuk soal hasil rancangan pada Gambar 8 juga merupakan dua permasalahan yang mungkin mampu mendorong level pemikiran siswa pada tahap aplikasi. Permasalahan pertama dari gambar ini merupakan permasalahan mengenai pecahan yang disusun menggunakan permasalahan sehari-hari, sedangkan permasalahan kedua dari gambar ini merupakan soal terkait topic relasi, di mana siswa hanya diminta untuk menentukan relasi yang mungkin dari dua himpunan hewan dan jenis makanannya.

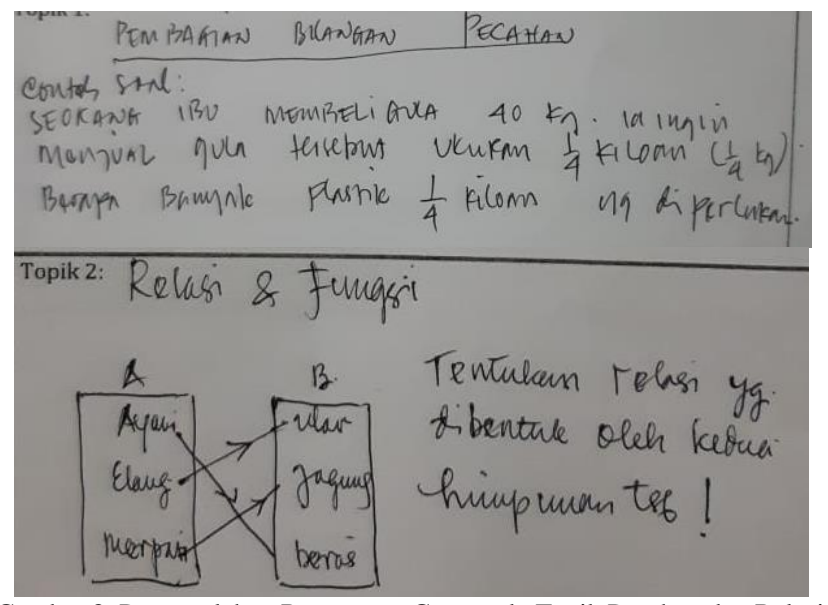

Gambar 8. Permasalahan Rancangan Guru pada Topik Pecahan dan Relasi 


\section{- - - Jurnal Pendidikan Matematika Indonesia \\ Volum 4 Nomor 2 bulan September 2019 Page 73 - 78 \\ p-ISSN: 2477-5967 e-ISSN: 2477-8443}

Hasil rancangan soal pada Gambar 9 terkesan sedikit berbeda dari soal lainnya yang telah dirancang guru. Jawabandaripermasalahanini tidakmelalui proses hitungmenghitung yang akan dilakukan oleh siswa. Pada soal ini, ketelitian dan kecermatan siswa dipadukan dengan pemahaman yang telah mereka ketahui akan diuji untuk menunjukkan berapa banyak persegi dan segitiga yang terdapat dari suatu bangun datar yang diberikan. Meskipun secara redaksional berbeda, permasalahan ini tetap hanya mampu mendorong kemampuan berpikir siswa pada level mengaplikasikan.

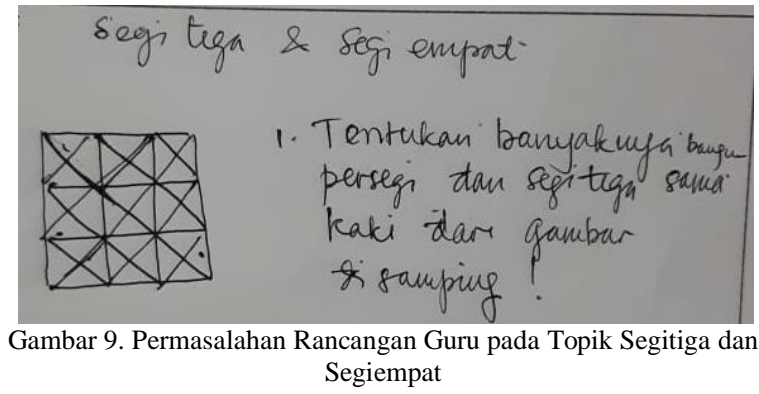

Gambar 10 menunjukkan hasil soal rancangan guru pada topik kesebangunan. Soal ini menggunakan kata "mengapa" sebagai kata tanyanya, sehingga soal ini dimaksudkan untuk memberikan penjelasan atau alasan terhadap kondisi tertentu. Ada 2 kondisi yang menjadi sorotan dari soal ini, yaitu mengapa $2 \times 3$ dan $4 \times 6$ dikatakan sebangun sedangkan $2 \times 3$ dan $4 \times 6$ dikatakan tidak sebangun. Melalui permasalahan ini, siswa akan diminta untuk mengingat kembali syarat dari dua hal dikatakan sebangun. Setelah itu, mereka akan memeriksa apakah syarat tersebut dipenuhi oleh dua kondisi di atas. Hasil inilah yang akan menjadi jawaban atas permasalahan pada Gambar 10 . Berdasarkan uraian ini, maka level kemampuan berpikir mengaplikasikan menjadi level kemampuan yang mungkin mampu didorong melalui permasalahan ini.

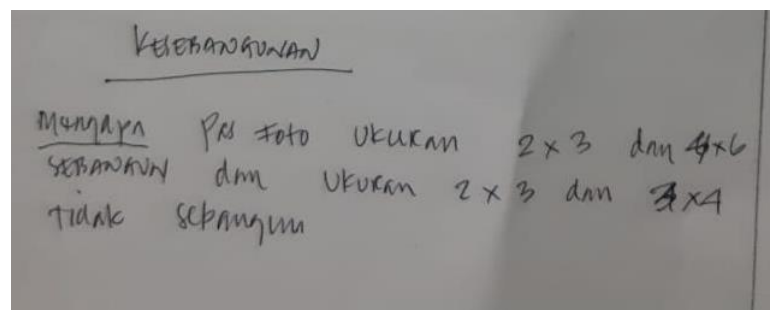

Gambar 10. Permasalahan Rancangan Guru pada Topik Kesebangunan

Rangkuman hasil analisis data terhadap soal hasil rancangan guru ditunjukkan oleh Tabel 2. Tabel 2 memberikan informasi mengenai level kemampuan berpikir siswa yang mungkin dapat didorong oleh setiap soal yang dikembangkan oleh guru. Kolom pertama menunjukkan kode guru yang menjadi subjek penelitian. Kolom kedua merupakan kode soal yang dirancang oleh guru, sedangkan beberapa kolom berikutnya merupakan level kemampuan berpikir berdasarkan Taksonomi Bloom.
Tabel 2 menunjukkan bahwa dari 14 permasalahan yang dirancang oleh 7 orang guru, 9 diantaranya berada pada level aplikasi, 1 permasalahan pada level pemahaman, 1 permasalahan pada level analisis dan 3 permasalahan pada level evaluasi.

TABEL 2

RINGKASAN LEVEL KEMAMPUAN BERPIKIR DARI SOAL HASIL RANCANGAN GURU

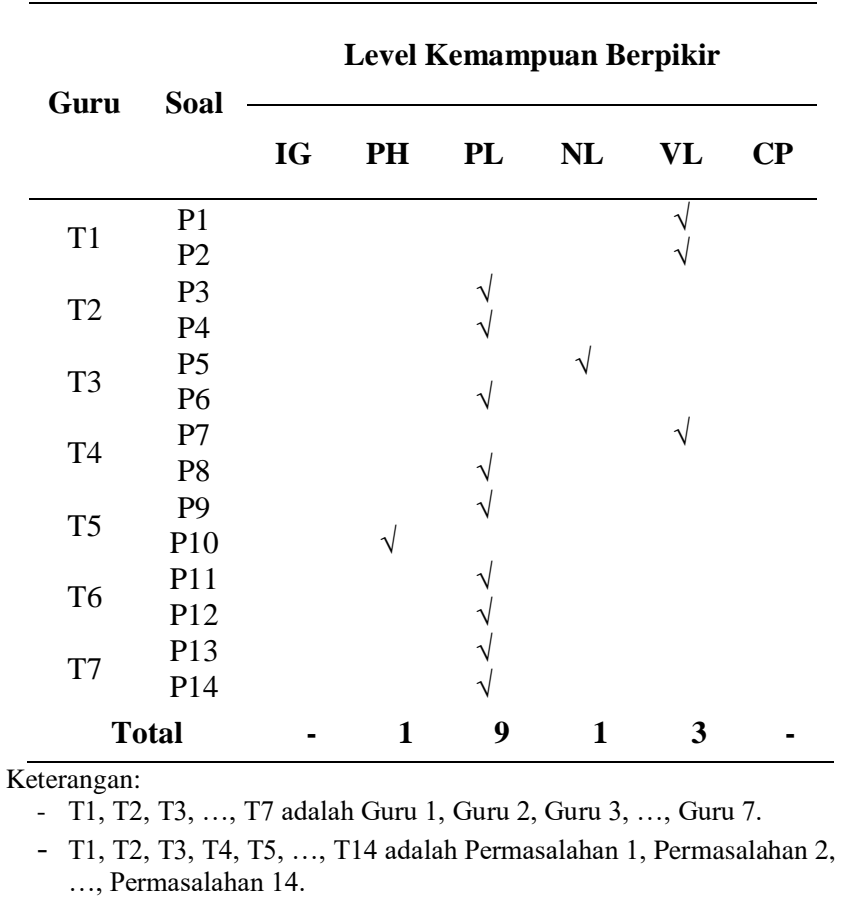

Tabel di atas menunjukkan bahwa kurang lebih $64 \%$ soal yang dibuat guru berada pada level mengaplikasikan. Penelitian dari Masduki (2013) juga menyebutkan bahwa soal-soal yang ada pada buku matematika SMP merupakan soal yang berada pada level menerapkan, namun bersifat rutin. Hasil ini didukung oleh hasil penelitian Giani dkk (2015), di mana $61.93 \%$ soal pada buku teks matematika kelas VII berada pada level mengaplikasikan. Bahkan, soalsoal matematika yang termuat dalam buku siswa Kurikulum 2013 masih berada pada level pemahaman seberar $68.01 \%$ (Rufiana, 2016). Tentu saja hal ini berdampak kepada level kemampuan matematika siswa di Indonesia yang masih berada pada level kognitif terendah (Masduki dkk, 2013). Dampak lain yang ditimbulkan adalah rendahnya penilaian guru yang hanya menekankan kepada kegiatan mengenalkan, mengingat kembali (Fatonah, 2005) dan mengaplikasikan pada level sedang.

\section{KESIMPULAN}

Berdasarkan uraian hasil penelitian maka dapat disimpulkan bahwa dari 14 permasalahan yang dirancang oleh 7 orang guru, 9 diantaranya berada pada level aplikasi, 1 permasalahan pada level pemahaman, 1 permasalahan pada level analisis dan 3 permasalahan pada level evaluasi. Ini artinya, kemampuan guru dalam membuat atau merancang suatu permasalahan hanya mampu dalam 


\section{일.}

Jurnal Pendidikan Matematika Indonesia

Volum 4 Nomor 2 bulan September 2019 Page 73 - 78

p-ISSN: 2477-5967 e-ISSN: 2477-8443 mendorong level berpikir siswa tingkat rendah. Soal/permasalahan yang disajikan guru kurang menantang siswa dalam berpikir, kurang mendorong kreativitas dan keterampilan siswa dan kurang memberikan siswa kesempatan dalam meningkatkan pemahaman mereka terhadap suatu konsep, mengaplikasikannya dalam permasalahan sehari-hari serta melihat hubungan antar konsep tersebut dengan konsep lainnya.

Untuk meningkatkan kemampuannya dalam membuat soal/permasalahan, perlu adanya suatu kegiatan yang dapat melatih guru. Diperlukan pula uji coba secara langsung terhadap soal/permasalahan rancangan guru untuk melihat dampak langsung dari soal tersebut terhadap kemampuan berpikir siswa.

\section{REFERENSI}

Anisah, A., Zulkardi, Z., \& Darmawijoyo, D. (2011). Pengembangan soal matematika model PISA pada kontenquantity untuk mengukur kemampuan penalaran matematis siswa sekolah menengah pertama. Jurnal Pendidikan Matematika, 5(1).

Bloom, B.S. (1956). Taxonomy of educational objectives: The classification of educational goals: Handbook I, cognitive domain. New York ; Toronto: Longmans, Green.

Fatimah, A. T., \& Amam, A. (2018). Rencana pelaksanaan pembelajaran matematika di sekolah menengah kejuruan. Jurnal Penelitian dan Pembelajaran Matematika, 11(2), 77-90.

Fatanoh, S. (2005). Aplikasi aspek kognitif (teori Bloom) dalam pembuatan soal kimia. Kaunia, 1(2), 151167.

Febrilia, B. R. A., \& Juliangkary, E. (2018, Oktober). Pengembangan modul masalah matematika berbobot (rich tasks) untuk guru matematika smp di kota mataram. In Prosiding Seminar Nasional II APPPI NTB 2018 (Vol. 1, No. 1).

Fitriati \& Novita, R. (2015). Pengembangan pendekatan rich task dalam meningkatkan mutu pendidikan matematika. Jurnal Numeracy, 2(1), 21-31.

Giani, G., Zulkardi, Z., \& Hiltrimartin, C. (2015). Analisis tingkat kognitif soal-soal buku teks matematika kelas VII berdasarkan taksonomi Bloom. Jurnal Pendidikan Matematika, 9(2), 78-98.

Juliangkary, E., \& Febrilia, B. R. A. (2018). Profil guru ditinjau dari permasalahan matematika yang dikembangkan: termasuk rich tasks atau bukan? JISIP: Jurnal Ilmu Sosial dan Pendidikan, 2(3).

Krathwohl, D. R. (2002). A revision of Bloom's taxonomy: an overview. Theoryintopractice, 41(4), 212-218.

Lewy, L., Zulkardi, Z., \& Aisyah, N. (2009). Pengembangan soal untuk mengukur kemampuan berpikir tingkat tinggi pokok bahasan barisan dan deret bilangan di kelas IX akselerasi SMP Xaverius Maria

Palembang. Jurnal Pendidikan Matematika, 3(2), 14-28.

Masduki, Subandriah, M.R., Irawan, D.Y., \& Prihantoro, A. (2013). Level kognitif soal-soal pada buku teks matematika SMP kelas VII, diseminarkan pada Seminar Nasional Matematika dan Pendidikan Matematika FMIPA UNY, ISBN : 978 - 979 $16353-9-4$

Mardhiyanti, D., Ilma, R., \&Kesumawati, N. (2011). Pengembangan soal matematika model Pisa untuk mengukur kemampuan komunikasi matematis siswa sekolah dasar. Jurnal Pendidikan Matematika, 5(1).

Mayer, R.E. (2009). Multimedia Learning $2^{\text {nd }}$ Edition. Cambridge: CambridgeUniversity Press.

OECD. (2009). PISA 2009 Assessment framework - key competenciesin reading, mathematics, and science. (online) Tersedia:

http://browse.oecdbookshop.org/oecd/pdf s/browseit/9809101E.PDF, diakses tanggal 9 Oktober 2018

Rufiana, I. S. (2016). Level kognitif soal pada buku teks matematika kurikulum 2013 kelas VII untuk pendidikan menengah. Jurnal Dimensi Pendidikan dan Pembelajaran, 2(2), 13-22.

Silva, E. Y., Zulkardi, Z., \&Darmawijoyo, D. (2011). Pengembangan soal matematika model PISA pada kontenuncertainty untuk mengukur kemampuan pemecahan masalah matematika siswa sekolah menengah pertama. Jurnal Pendidikan Matematika, $5(1)$.

Siregar, Y. (2015). Kompetensi Guru Dalam Bidang Strategi Perencanaan dan Pembelajaran Matematika. Formatif: Jurnal Ilmiah Pendidikan MIPA, 3(1), 39-48.

Siswono, T. Y. E. (2007). Desain Tugas untuk Mengidentifikasi Kemampuan Berpikir Kreatif Siswa dalam Matematika. Tersedia: http://tatagyes. files. wordpress. com/2007/10/tatag_jurnal_unej. pdf.[7 januari].

Thompson, T. (2008). Mathematics teachers' interpretation of higher-order thinking in Bloom'staxonomy. International electronic journal of mathematics education, 3(2), 96-109.

World Bank Human Development Department East Asia and Pasific Region. (2010). Inside Indonesia's Mathematics Classroom: TIMSS Video Study of Teaching Practices and Student Achievment. Jakarta: World Bank Office Jakarta. 